\title{
EDUCATION AS A FACTOR OF AWARENESS DEVELOPMENT OF ORGANIC PRODUCT CONSUMERS
}

\author{
Gordana Tomića , Maja Đuricaa \& Nenad Đokićb \\ ${ }^{a}$ Belgrade Business School, Belgrade, Serbia, \\ ${ }^{b}$ Higher School of Professional Business Studies, Novi Sad, Serbia
}

\begin{abstract}
Organic agriculture provides good quality products, the development of sustainable agriculture, environmental protection and economic efficiency. To develop a habit of consuming organic food, as is case with all habits, it is necessary to educate the younger population, so that they can become accustomed to the fact that organic food is a source of both human health and a healthy environment. Therefore, educational institutions should initiate actions in order to develop awareness of the importance of healthy and safe food (especially fresh fruits and vegetables) among youth. This action has already been carried out in some countries.
\end{abstract}

Keywords: organic agriculture, consumer education, promotion of organic products, educational institutions.

\section{Situation and basic characteristics of organic agriculture in the world}

Standards that characterize organic agriculture, which are prescribed by IFOAM (International Federation of Organic Agriculture Movements), were established in 1974. Following this, some countries (Austria, France, Denmark and Spain) developed their own regulations on organic agriculture. Under its regulation (EEC) 2092/91, the European Union presented its standards of organic agriculture (1991). Afterwards, many other states developed their own regulations. The first guidelines for organic food devised by the Codex Alimentarius (Instructions for the manufacturing, processing, labeling and marketing of organic food), a joint program of the UN, WHO (World Health Organization) and FAO, were published in 1999.

IFOAM defines organic agriculture in the following way: "Organic agriculture is a production system that maintains the health of soil, ecosystems and people. It relies on ecological processes, biodiversity and cycles adapted to local conditions but not on the use of ingredients with undesirable effects. Organic agriculture combines tradition, innovation and science for the benefit of the shared environment and promotes fair treatment and good quality of life for all people in the certain area."

Organic production is characterized by the conversion period (transition period), which can last from 1 to 3 years, depending on the certifying body, which means that the total output is adjusted to the standards of organic production.
The goals of organic agriculture are represented in the new regulation of the Council Regulation (EC) 834/2007 which has been in force since 2009, which replaced the regulation (EEC) 2092/91. Goals are the following [Schmid et al., 2008]:

1. Establishment of a sustainable management system for agriculture where:

a) natural systems and cycles are taken care of that maintain the health of soil, water, plants and animals and establishes the balance between them;

b) contributes to a high degree of biological diversity;

c) energy and natural resources (water, soil, organic substances and air) are used in a rational way;

d) the high standards of animal welfare, which require that their needs are met, are complied with.

2. Production of high quality products and

3. Consumer satisfaction, i.e. meaning that the process of producing food and other agricultural products do not endanger the environment, human health, plants and animals, as well as their welfare.

Organic agriculture in the world is booming, both for environmental reasons (in order to prevent further collapse) but also due to the health of the population and profitability. Countries that have most of the organic agricultural land are Australia, with 12.00 million ha, followed by Argentina with 4.40 million hectares and the USA with 1.95 million ha. (Chart 1.). 


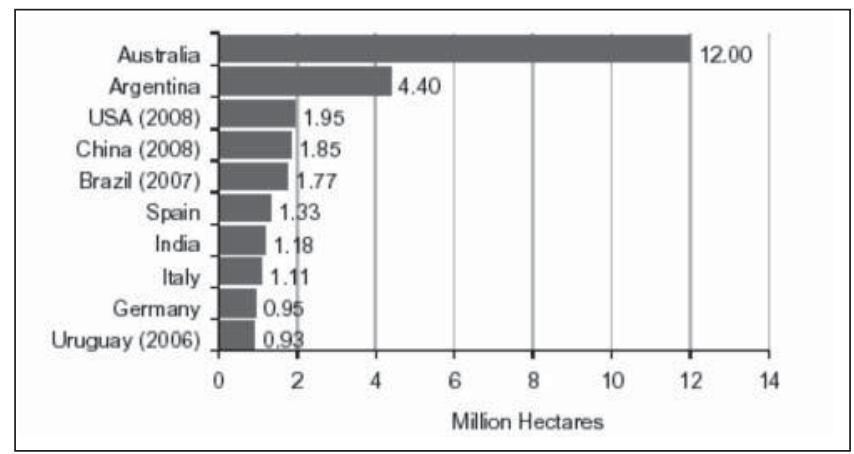

Chart 1. World: The ten countries with the most organic land in 2009 Source: Willer [2011]

The country with the largest share of organic land is the Falklands, with $35.7 \%$, followed by Liechtenstein, with $26.9 \%$ and Austria, with $18.5 \%$ (Chart 2).

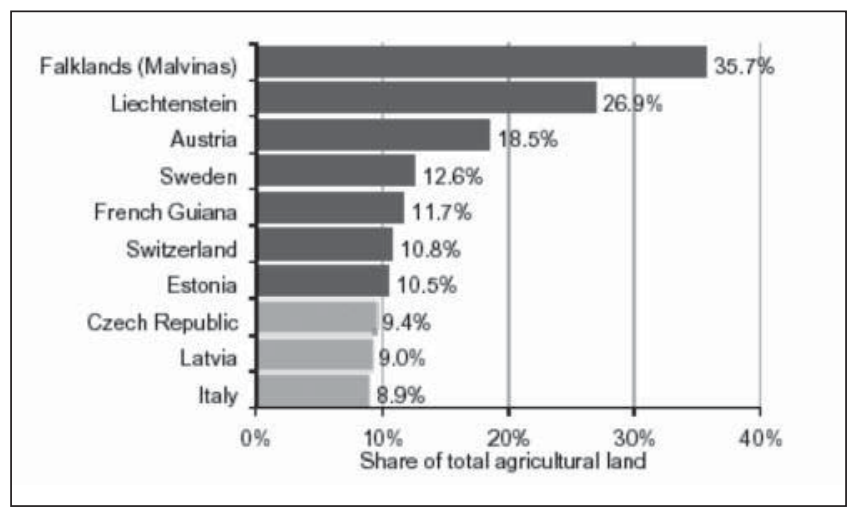

Chart 2. World: The ten countries with the largest share of organic agricultural land in 2009

Source: Willer [2011]

The biggest producers of organic food in the world (2009) are India, where there are 677,257 producers, then Uganda, with its 187,893 producers and Mexico, with up to 128,862 (Chart 3).

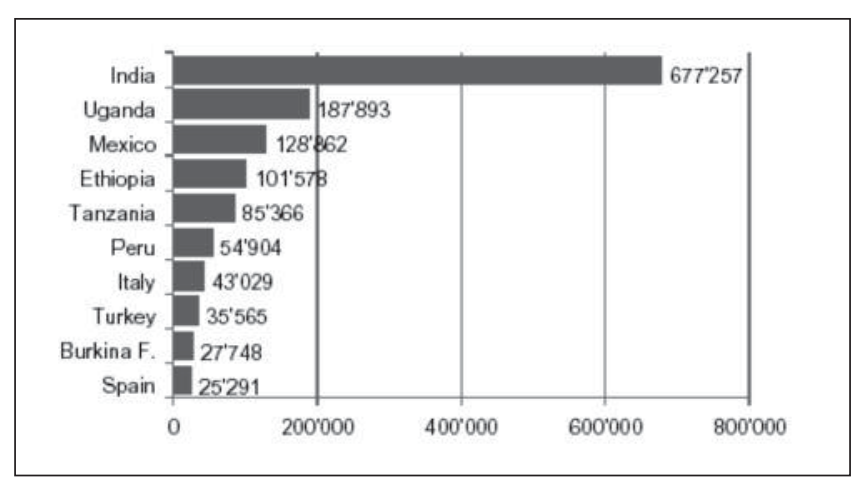

Chart 3. World: The ten countries with the largest number of organic producers in 2009

Source: Willer [2011]

Demand worldwide for organic products is very high, because consumers want healthy and safe food, and most of them are aware that organic farming preserves the environment. The international sales of organic products in 2009 amounted to 54, 9 billion of U.S. dollars. The greatest demand for organic products is in the U.S., where sales totaled 17,835 million Euros, followed by Germany with 5,800 million Euros and in the France with 3,041 million (Chart 4).

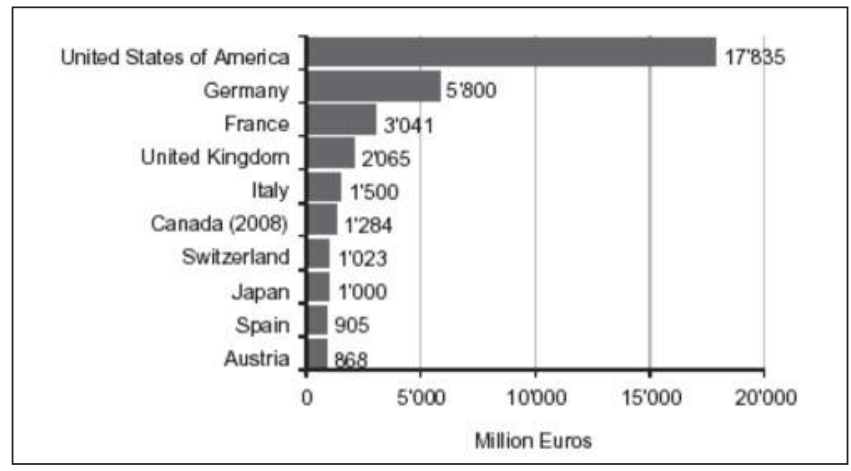

Chart 4. World: The ten countries with the largest markets for organic food in 2009

Source: Willer [2011]

Thus, the greatest demand for organic products is in North America and Europe. Significant producers and exporters of organic food are Asia, Latin America and Australia.

\section{Education of consumers of organic products}

While conducting consumer research target groups should be determined. Then one should take and examine the results of the research carried out by Hartman Group. A welldesigned study was conducted by the Hartman Group, which established the relationship and attitude of consumers towards food that is "good for the environment" in the centre. The results were published in two volumes in 1996 and in 1997, and some of these results are as follows [Karuki, Matheson, 2009]:

- $48 \%$ of respondents will not buy this food because they are not interested (18\%) and because the market is saturated $(30 \%)$.

- Half the population makes the target group for this food. Those who are really willing to buy these foodstuffs are known as "real naturalists" according to the Hartman report, and they represent $7 \%$, and others who are just willing to buy make up the other $45 \%$. These $45 \%$ were classified into three categories. The first group is called the "new green trend" and represents $23 \%$. They are determined about shopping provided that the product meets their expectations on price and availability. "Rich healers" belong to the second category, and they make up $12 \%$. Their decision to make purchases increases if they feel that the offered good is a real product and think that it has a higher nutritional value. The next $10 \%$ represent the third category which consists of "young recyclers" 
who, like the second category, are less committed to this food but their opinion is that environmental protection is an important field.

- For consumers, the price, taste, quality, accessibility and usability are the main criteria in the purchasing process. That based on the tags, consumer and believes in the product and that product label is understandable.

- The greatest concern among respondents is the pollution of surface and ground water with pesticides, then the effect of pesticides on birds and wildlife, but they are also concerned that the food contains pesticide residues.

- Many show their concern for the environment, but on the basis of their behavior, they are not in line with their concerns. Based on responses from respondents in terms of purchasing behavior, the Hartman Group realized that only half of the respondents transformed their words into action.

All activities that involve obtaining a true picture about organic products should be directed to consumers. They are a major factor because their demand depends on the offer of organic products in the market. Primarily through the media (as the prime media), customers should be presented with a logo that presents certified organic product, so in that way they can be sure what they are buying. Consumers should be aware that this logo means that the product contains at least $95 \%$ of the ingredients of organic origin, that inspection requirements are met, that the packaging of products meets the mandatory criteria and that the organic product comes directly from the manufacturer. It is necessary to educate consumers about organic farming through educational series where experts as well as known producers in this field would inform them about the benefits of consuming organic foods. Then, in various retail outlets, samples should be made available, in order that the population be able to try organic products and thereby encourage demand. Also, celebrities have a large impact on consumers because most of the young population identifies with them. Through the campaign, they are supposed to provide consumers with a message that eating organic food protects the health and the environment, (campaign can be supported by the Ministry of Agriculture, as well as by the companies involved in the production of organic food which want to position themselves in the market). Most recently the younger population is turning to social networks so it is advisable to work on creating sites about organic products.

The consumption of organic food reflects the attitude of consumers towards health and culture of the body and the relation to the environment protection. To develop a habit of consuming organic foods, as it is case with all habits, one should start educating the younger population so that they can get accustomed to the fact that organic food is a source of both the human health and the healthy environment. Therefore, an action should be initiated in order to develop awareness of the importance of healthy and safe food (especially fresh fruits and vegetables) at schools and universities. Many educational institutions have canteens or cafeterias with food, i.e. fast food. Therefore, the Ministry of Education should initiate an action to introduce organic food in coordination with the Department of Organic Agriculture within the Ministry of Agriculture. All key actors suggest that being in charge of the education of young people would have a positive impact on the health of pupils and students, since obesity in young people is a noticeable trend. The importance of organic food should be promoted to the students at the school level, but it is very important that a person who is an expert in this field makes this topic interesting and acceptable to students by means of understandable and simple language because it is possible that too many facts or incomprehensible and unknown technical terminology will create resistance in children. A person who speaks to children should be primarily a pedagogue who can, on the basis of short and interesting presentation, understand and monitor the reactions of students and maintain their attention.

As far as the faculties are concerned, it is necessary to educate students about the values of organic agriculture, as well as provide them an opportunity to consume organic food in cafeterias/canteens. Faculties, such as schools, should direct the cafeteria to sign deals with certified organic farmers. These contracts would provide data on the quantity they need, about the prices of these products (lower prices should be offered in relation to the market since these are educational institution and they can stimulate demand among young people), payment terms and delivery time so the products would be available at any time, as well as requirements for packaging. This would in some way help to develop organic agriculture because organic producers would have a safe market of educational institutions and this would also help the local economy. Many developed countries have introduced organic food in restaurants on their faculties because they are aware of the benefits of eating organic foods.

In America, there is the program from farm to school, and in order to be successful this program requires good buying, selling and distribution systems. Successful distribution approaches in the program from farm to school, according to Kelly Sanger from the Department of Small Farm Agriculture and Direct Marketing in Washington, are namely [Bellows et al, 2009]:

Private farmers belong to certain unions within which they organize themselves so that their products are collected, processed and then distributed to schools and/or institutions. An example of this practice is a community of small farmers the New North Florida and the program for the student cafeteria at the University of Wisconsin.

The connection between growers and buyers in the institutions was created with the help of nonprofit organizations. Institutions order food through an organization which comes into contact with farmers in order to execute orders. An example is the Iowa project for meals at the State University of Iowa.

Schools purchase products in local markets, and to obtain adequate quantities of products and the products they want, 
ordering is done in advance with the seller. In order that products are ordered, picked up and transported the coordinator is required. An example is a school district in Santa Monica in Malibu and Western Student Center for Food and Justice.

The program of fresh products includes procurement of fresh products which are used for school lunches through the Ministry of Defense. The Ministry buys food from farmers and then it sells food to schools, but delivery is not included. Examples include North Carolina, Florida, Tennessee, Kentucky and Washington State, which work with the U.S. Department of Defense in coordination with USDA's initiative for small farm/school meals. California and Illinois also have pilot programs.

Intermediaries between farms and campuses are also private companies that have contracts with colleges and universities, and are required to provide services of orders, procurement and delivery of food. Examples are the Aramark at Slippery Rock University in Pennsylvania, Burlington Food Service at Midlberi College in Vermont, Bon Appetite at Evergreen State College in Washington.

Within the U.S. Department of Agriculture, there is a program that includes an association of American schools for food service. This program as suggested by program Farm Bill in 2002, supports the introduction of the program from farm to school and other programs for feeding the community). The USDA coordinates the implementation of the supplies to create pilot programs, to provide nutrition services in schools, to increase the amount of fruits and vegetables, and to enable children to get these services for free. Pilot projects are being implemented in Indiana in Michigan, Iowa and Ohio, where each out of 25 schools in the state can receive up to $\$ 50,000$ so that children can receive free fresh and dried fruits and vegetables.

Most countries should go in this direction, which means that colleges and schools could work directly with farmers, where there would be a coordinator within the Council on Nutrition at the educational institutions who would monitor all the necessary actions. In order to earn the trust between both sides, it is necessary to start with one educational institution at a time. It is assumed that initially there would be various problems, but all that needs to be overcome in order to provide opportunities for young people to consume organic food. Also, main actors may be NGOs, private companies, as well as the Ministry of Agriculture which may be the link between educational institutions and farmers. In order that all of this could come to life requires a strong promotion with regard to the issue of organic food. The media and social networks have a major impact on young people, and states should give maximum support in promotion because a healthy nation and healthy environment are vital for every country.

\section{Conclusion}

There are more and more appeals for consumers to eat organic food as this protects their health and helps to protect the environment. Consumers should be educated about the benefits they receive when eating this kind of food and that the higher prices the pay for organic products are not so high in the long run, when you take into account that the consumption of unsafe food threatens the health and therefore a huge amount of money should be allocated for health care.

It is important to promote organic products, and increase their "presentation" in educational programs, because the goal is for young people to understand the importance of consuming healthy and safe food, which in perspective leads to a healthier workforce, and therefore higher productivity in the production process.

\section{References}

Bellows, B., Defour, R. and Bachmann, J., (2009): Bringing local food to local institutions. http://www.attra.ncat.org.

Karuki, A. and Matheson, N. (2009): „Green“ Market for Farm Products. http://www.attra.ncat.org

Schmid, O., Dabbert, S., Eichert, C., Gonzálvez, V., Lampkin, N., Michelsen, J., Slabe, A., Stokkers, R., Stolze, M., Stopes, C., Wollmuthová, P., Vairo, D. and Zanoli, R. (2008): Organic Action Plans: Development, implementation and evaluation. A resource manual for the organic food and farming sector. Edited by Schmid O., Stopes C., Lampkin N. and Gonzálvez V. Research Institute of Organic Agriculture FiBL, Switzerland and IFOAM-EU Group, Belgium.

Willer, H. (2011): Organic Agriculture Worldwide, Key results from „The World of Organic Agriculture 2011 “, published by FiBL and IFOAM, http://www. Fibl.org

http://www.organic-world.net

http://www.ifoam.org

http://www.organic-europe.net 